\title{
The Role of Micropropagation in Producing Specific Pathogen-tested Plants
}

\author{
Adam Dale ${ }^{1}$ \\ Department of Plant Agriculture-Simcoe, University of Guelph, 1283 Blueline Road, \\ P.O. Box 587, Simcoe, Ont. N3Y 4N5, Canada \\ Becky R. Hughes \\ New Liskeard Agricultural Research Station, University of Guelph, P.O. Box 6007, \\ New Liskeard, Ont. POJ 1P0, Canada \\ Danielle Donnelly \\ Department of Plant Science, Macdonald Campus of McGill University, 21111 Lakeshore Road, \\ Ste-Anne-de-Bellevue, Que. H9X 3V9, Canada
}

Additional index words. anthracnose, certification, Colletotrichum, plant propagation

\begin{abstract}
Micropropagation of strawberries is an extremely effective tool to rid strawberry plants of Colletotrichum infections. The continued health of these plants depends on a vigorous sanitation program throughout the nursery system in North America. Propagating healthy strawberry plants requires a series of steps: plants are micropropagated, virus-tested, screened for fungal and bacterial pathogens, and finally grown under strict guidelines for two growing seasons in propagator's fields. In the propagator's fields, the plants are inspected for visual symptoms of diseases and checked for trueness-to-type. This paper reviews the protocols used to develop specific pathogen-tested strawberry plants in Ontario and, where appropriate, discusses alternate techniques.
\end{abstract}

Micropropagation has been used successfully for strawberry (Fragaria $\times$ ananassa L.) for over 30 years (Boxus, 1974; Swartz and Lindstrom, 1986). This has been applied, often together with thermotherapy, to produce specific pathogen-tested plants (Boxus, 1989), rapidly multiply new cultivars, and conserve germplasm (Damiano, 1980). Also, micropropagation has been used to increase plants that have been genetically transformed with traits of commercial interest (Jelenkovic et al., 1991).

Despite the successful application of micropropagation techniques to strawberry for three decades, several questions remain: first, are mutation rates increased in micropropagated strawberry plants or do they reflect a similar incidence of mutable genes as conventional propagation techniques? Second, is relative susceptibility to diseases, insects, or herbicides affected by micropropagation? And finally, how do we explain physiological differences, such as extreme vigor and juvenility of the plants following micropropagation compared with conventionally produced propagules?

Anthracnose or black spot, incited by Colletotrichum spp. [C. acutatum J.H. Simmonds, C. fragariae Brooks, or C. gleosporioides Penz.(Penz.\&Sacc.)] has over the last 20 years developed from a localized, but serious, disease of strawberry, in hot humid areas of the southern United States to one that has worldwide prominence (Smith, 2007). There is now a considerable body of evidence to suggest that spores are carried on strawberry plants moved by the nursery trade throughout, within, and between countries

${ }^{1}$ To whom correspondence should be addressed; e-mail adale@uoguelph.ca
(Freeman, 2007) and that methods are needed to prevent this inadvertent spread. To break the cycle of anthracnose incidence and spread, a two-pronged approach is advocated, involving rotation and specific pathogentested plant distribution.

The Colletotrichum spores that spread the disease are relatively short-lived conidia, so fields can be rotated out of strawberry plants to eliminate the disease locally (J. Maas, personal communication). Specific pathogentested strawberry plants can be produced by meristem tip culture/thermotherapy and be used as the basis of a nursery trade that provides healthy plants with negligible risk of carrying this pathogen.

In terms of the discussion of Colletotrichum, the critical step is to produce specific pathogen-tested plantlets from virus-tested stock plants. These vegetatively vigorous plantlets which are not infected with the fungus are used for nursery propagation. This paper reviews the protocols used to develop specific pathogen-tested strawberry plants in Ontario and, where appropriate, discusses alternate techniques. To help explain our protocol, a schematic is given (Fig. 1). For convenience, the discussion is divided into two parts: the first part deals with virus testing and elimination using meristem tip culture and thermotherapy, and the second part deals with the protocols used in the nursery to keep ex vitro-specific pathogentested plants healthy.

\section{VIRUS INDEXING, ELIMINATION,} AND MICROPROPAGATION

Before plants can be designated specific pathogen-tested, they must be virus-tested and indexed for bacteria and fungi. Viruses may need to be removed by micropropagation and thermotherapy, which may involve two or three meristem tip isolations as the repeated indexing procedures are carried out.

Production of virus-tested stock plants. Initially, the stock plants may be of uncertain disease status if they have not come from a known specific pathogen- or virus-tested source. Ideally, these plants will be growing vigorously and producing runners. The runner tips are easier to decontaminate than the crowns, and their meristems are usually vegetative. Runner tips or runner plants should be collected in the spring or summer, as bacterial and fungal contamination is less than in the fall and winter (López-Aranda et al., 1994; Swartz and Lindstrom, 1986). Even though the stock plants may look free of fungal diseases, they should be treated with a fungicide to kill any latent spores.

Standard protocols have been published for strawberry micropropagation (Boxus et al., 1984; Jungnickel, 1988; Martinelli, 1992). The size of the dissected portion of the shoot placed into culture (explant) and the application of thermotherapy (heat treatment) are the key factors in virus elimination (Belkengren and Miller, 1962). Researchers generally use the term "meristem tip culture" when the dissected portion of the shoot is $<1.0 \mathrm{~mm}$ in length with an apical dome and one pair of leaf primordia and "shoot tip culture" when the excised shoot is $\geq 1.0 \mathrm{~mm}$ with more than one pair of leaf primordia present (George and Sherrington, 1984). However, in strawberries, our meristem tips are usually $<0.5 \mathrm{~mm}$, and our shoot tips are $>0.5 \mathrm{~mm}$. Smaller explants allow viruses to be eliminated more frequently; however, larger explants have a better chance of surviving provided bacterial and fungal contaminants are not present (Boxus, 1989; George, 1993). Although some strawberry viruses are eliminated quite effectively in meristem tip culture, thermotherapy of the source plant 


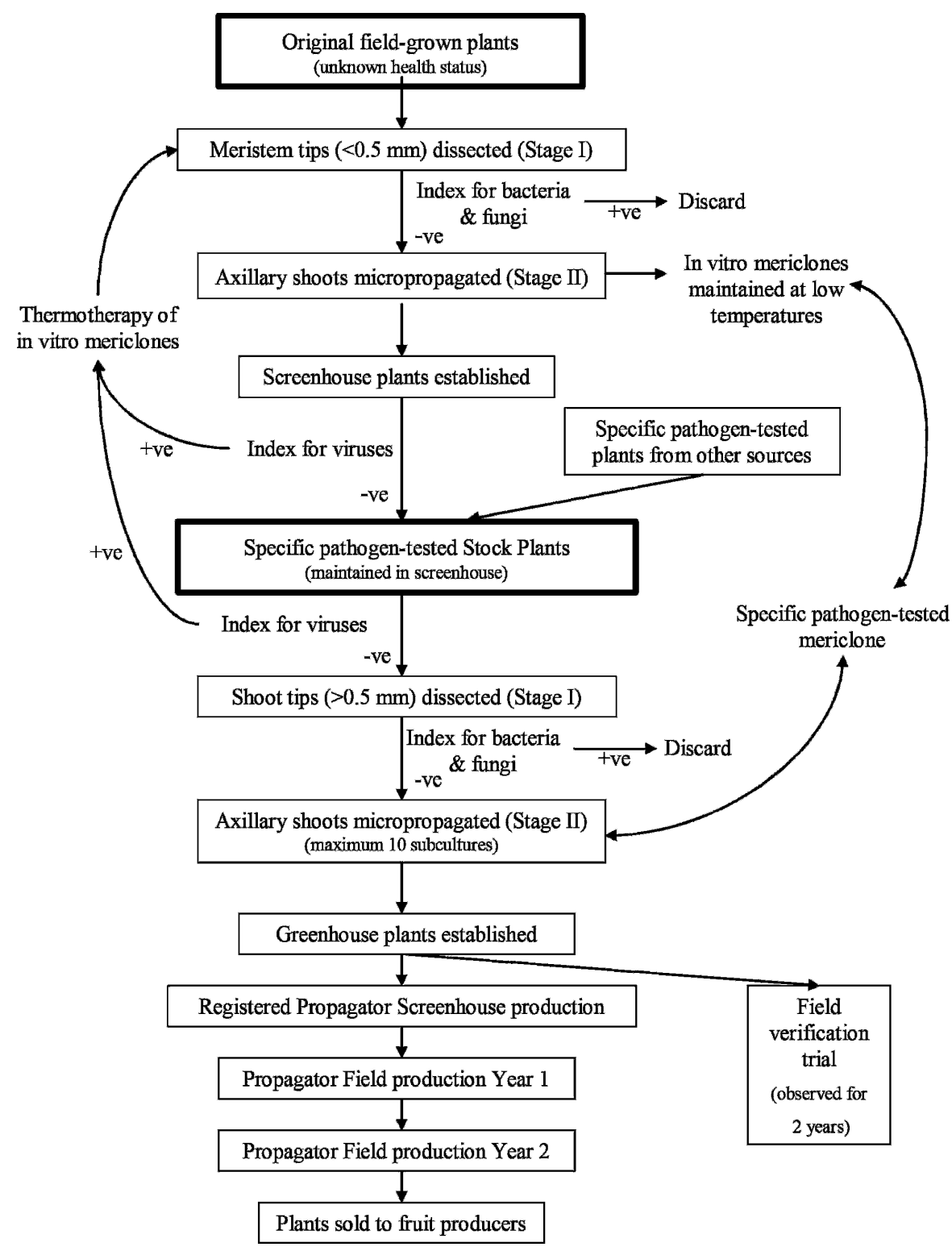

Fig. 1. Schematic flow chart of the steps required to produce specific pathogen-tested strawberry plants that are essentially free of Colletotrichum spp. Boxes in bold indicate where plants can enter the program.

was recommended before meristem tip culture to increase the efficiency of virus elimination (reviewed by Boxus, 1989).

We use meristem tips $<0.5 \mathrm{~mm}$ long to establish new cultivars because the plants we receive are usually infected with one or more viruses. The meristem tips develop into shoots that are micropropagated through axillary shoot multiplication once every 4-6 weeks for a maximum of 10 subcultures. Shoots are indexed for the presence of bacteria and fungi on the first or second subculture. Shoot cultures that test negative for bacteria and fungi are subcultured onto rooting medium, and the rooted plantlets are transferred to the screenhouse.

Once established in the screenhouse, plants derived from each meristem tip source clone (mericlone) are repeatedly tested for viruses using standard protocols for virus indexing (Martin, 2001). We use a series of tests including grafting to the
Mycoplasmas and some viruses can be eliminated by meristem tip culture alone, while others require thermotherapy to the source plant followed by meristem tip culture (Boxus et al., 1984; Converse, 1987). Some micropropagation facilities routinely heattreat, whether plants have tested negative for virus or not. This decision is based on reports that the growth and survival rate of heat-treated strawberry meristems improved as were their multiplication rates in culture and subsequent runner production in the field (Boxus et al., 1984). However, these results may relate to cytokinin exposure during micropropagation. Furthermore, thermotherapy is thought to impede virus multiplication through cell damage, including extensive membrane disruption (Sward and Hallam, 1977), so we prefer to test our meristem tip source plants and then apply in vitro thermotherapy only if no mericlones test negative for virus.

Once a plant has been designated specific virus-negative, it must be kept isolated, in an appropriate facility, from all other plants which are virus-infected or of unknown health status. Plants that assay negative for viruses can be micropropagated beginning with larger explants, i.e., shoot tips instead of meristem tips.

Indexing for bacteria and fungi. Micropropagated plants must be indexed for bacteria and fungi that cause plant disease or have the potential to interfere with plantlet growth in culture. Indexing is done readily on meristem tip-derived shoots.

Strawberry shoots are indexed for bacteria and fungi at the time of the first or second subculture and annually thereafter. This is done because plants may contain latent contaminants that survive under unsuitable conditions and only become visible under environmental conditions that optimize their development (Jungnickel, 1988). This is often the case with endogenous bacteria (Leifert et al., 1989). The base of the shoot is streaked across three types of agar: potato dextrose (PDA), malt extract peptone, and yeast extract (Jungnickel, 1988). Any shoots that assay positive for bacteria or fungi are discarded, whether they appear visibly contaminated or not. Colletotrichum spp. grow well on PDA and can readily be detected at this stage. However, it is highly unlikely that parasitic fungi, such as Colletotrichum spp., can spread undetected in vitro as they are rapidly colonize the plant cultures (Damiano, 1980; Kunneman and Faaij-Groenen, 1988).

Khayat et al. (1997) effectively cleaned strawberry plants heavily infested with fungi including Colletotrichum and Fusarium when they rigorously disinfested explants and then meristem tip-cultured them. Soil fungi such as Verticillium and Phytophthora were also eliminated through these procedures (Boxus, 1989; Jungnickel, 1988; Martinelli, 1992). We surface-disinfest using an initial $1-\mathrm{h}$ agitated bath with $0.01 \%$ sodium hypochlorite and $0.5 \%$ Tween 20 , followed by a 20 -min agitated bath with $1.0 \%$ 
sodium hypochlorite and a final 10-min agitated bath in sterile water.

\section{NURSERY PROPAGATION}

Once micropropagated shoots are rooted in vitro, they are transferred into plugs or pots in the greenhouse to acclimatize. These specific pathogen-tested plants are made available to approved (registered) plant propagators. Then, depending on the procedures of the applicable plant propagation program, these are grown in a screenhouse and then for several years in the field before plants are sold to the fruit grower (Fig. 1).

Two questions arise here: 1) how do we keep these plants clean in the screenhouse and field, and 2) are there differences in the relative susceptibility of micropropagated plants and conventional propagules to disease?

\section{Sanitation procedures}

Various sanitation procedures can be used to help keep the plants healthy, and prevent the spread of Colletotrichum to the plants.

Greenhouse. Plantlets are usually grown in plugs or small pots before they are used to produce the next generation of propagules. In the greenhouse, the plants are isolated from any plants that may be contaminated with Colletotrichum or any economically important disease. A pasteurized potting mixture is used, along with a strict sanitation program (e.g., leaf removal, careful watering, weeding), and the plants are monitored for insects and diseases. Usually, the plants are grown in the greenhouse for a short time before they are moved to a screenhouse. However, at this stage the plants are handled very easily, and it may be appropriate to coldtreat the plants ( 1 to $5^{\circ} \mathrm{C}$ for 6 weeks) before they are moved to the screenhouse, as this synchronizes and improves their growth (Swartz and Lindstrom, 1986).

Screenhouse. The specific pathogen-tested plants are grown in the screenhouse for one growing season to maintain their health status and maximize runner production. Practical experience has shown that disease problems may be reintroduced if the plants are maintained in the screenhouse for more than one season (Gaines, 2005). Many standard protocols have been published that describe screenhouse sanitation (e.g., Canadian Food Inspection Agency, 2004). These require the plants to be separated from any whose disease status is unknown or questionable, to be regularly monitored for insects and diseases, and to have fungicides routinely applied. The risk that the plants will be infected by Colletotrichum at this stage is low, but spores can be transported into the screenhouse from the field (Freeman, 2007). Screenhouse workers must wear clean, dry footwear and clean clothes, as well as schedule work in the screenhouse before their field work.

Field. This is where most infections of nursery stock occur. Normal sanitation issues apply. For example, fields must be rotated to eliminate residual spores. Soil fumigation may reduce the number of spores in the field more rapidly. The healthy plants must be isolated from any nursery material that is not specific pathogen-tested. Colletotrichum spp. have a broad host range, so blocks of plants must be separated from the field edges to avoid contamination from wild or weedy hosts (Freeman, 2007). However, the most common source of spread and contamination is from field equipment and workers. Nursery managers must sequence field work from the cleanest plantings to the least clean and disinfect equipment whenever this sequence cannot be maintained.

\section{Relative susceptibility of \\ micropropagated plants to disease}

Concern has been raised that micropropagated plants can be more susceptible to diseases than conventionally propagated ones because the plant tissue is growing very vigorously, may be more succulent, and is acclimatized to the screenhouse but not the field environment (Boxus, 1989; Jungnickel, 1988). Damiano (1980) found this to be untrue for strawberry microplants; these were not more sensitive to infection by soil parasites than conventionally propagated plants. Shoemaker et al. (1985) found that micropropagated strawberry plants had a cultivardependent shift in susceptibility to Phytophthora fragariae and Verticillium albo-atrum. Tissue-cultured 'Raritan' plants were more susceptible to these diseases than runner plants. However, tissue-cultured 'Tribute' plants had a similar susceptibility to that of runner plants. In raspberry, micropropagated plants were more susceptible to herbicide damage (Neal et al., 1990). However, our experience and that of others (Shoemaker et al., 1985) would suggest that any potential differences disappear with time and successive runner generations.

\section{Field verification}

In the field, the plants need to be checked for trueness-to-type and for any visible mutations.

Swartz et al. (1981) found that mericlones were uniform in performance but concluded that a sample population of individual cultivars should be prescreened before the plants are sold to detect any possible genetic mutations. In the Ontario program, we limit the total number of mericlones from each cultivar or selection to enable each one to be evaluated thoroughly. To detect any mixes due to human error or any gross vegetative or reproductive abnormalities, a subsample of the micropropagated plug plants and a subsample of vegetatively propagated plants from the stock plants of each cultivar are planted into an annual field-verification trial. In these trials, plants are observed for vegetative characteristics, flowering, and fruiting over 2 years, and the results are available to the propagators before plants are sold.

\section{CONCLUSIONS}

Micropropagation of strawberry plants is an extremely effective tool to eliminate - maintain strawberry plants free of-Colletotrichum infection. The continued health of these plants depends on a vigorous sanitation program throughout the nursery system in North America.

Genetic mutations have occurred in micropropagated plants. However, the general consensus is that the incidence of mutations in micropropagated and vegetatively propagated plants is the same, but because more micropropagated plants can be produced with greater uniformity, mutations are easier to identify (Swartz and Lindstrom, 1986). In our experience, once the plants have been designated virus-negative following testing and their cultivar status is confirmed, they can be micropropagated safely using published techniques which recommend low cytokinin levels and a limited number of subcultures (Boxus et al., 2000). Reduced plant stress, reasonable subculture intervals, and a quality-control program further reduce the chances of genetic variability in the plants sold to fruit growers (Hughes, 2002).

Initially, ex vitro transplants may be more susceptible to fungal infections. However, experience suggests that this susceptibility disappears with time and successive runner generations.

The risk that specific pathogen-tested plants will be reinfected with Colletotrichum increases with time in the field. Field production can be reduced by 1 year if the nursery system is front-loaded with micropropagated specific pathogen-tested plants and the screenhouse phase or if 1 year in the field is omitted. Maximizing in vitro multiplication is extremely cost-effective because the major costs associated with micropropagation involve culture establishment and indexing for the various diseases.

One disadvantage of front-loading the system could be that the plants are more vegetatively vigorous (Cameron et al., 1985). However, vegetative vigor declines with time, and any initial vigor of ex vitro plants can be exploited to give greater runner production, which translates to increased marketable productivity.

Specific pathogen-tested micropropagated plants can be used effectively as a tool to eradicate Colletotrichum infections throughout North America. However, it depends on considerable cooperation and openness between the different nursery systems in North America. Interstate and international trade in strawberry plants will continue as some environments are preferred for the production of specific types of plants. So, inevitably, common standards of health and sanitation will be demanded by governments and the industry.

\section{Literature Cited}

Belkengren, R.O. and P.W. Miller. 1962. Culture of apical meristems of Fragaria vesca strawberry plants as a method of excluding latent $\mathrm{A}$ virus. Plant Dis. Rpt. 46:119-121.

Boxus, P. 1974. The production of strawberry plants by in vitro micropropagation. J. Hort. Sci. 49:209-210. 
Boxus, P. 1989. Review of strawberry mass propagation. Acta Hort. 265:309-320.

Boxus, P., C. Damiano, and E. Brasseur. 1984. Strawberry, p. 453-486. In: P.V. Ammirato, D.A. Evans, W.R. Sharp, and Y. Yamada (eds.). Handbook of plant cell culture, Vol. 3. Macmillan, New York.

Boxus, P., A. Jammali, J.M. Terzi, and O. Arezki. 2000. Drift in genetic stability in micropropagation: the case of strawberry. Acta Hort. 530:155-161.

Cameron, J.S., J.F. Hancock, and T.M. Nourse. 1985. The field performance of strawberry nursery stock produced originally from runners or micropropagation. Adv. Strawberry Prod. 4:56-58.

Canadian Food Inspection Agency. 2004. Production, maintenance, multiplication and certification of nuclear stock seed potatoes, p. 27. Directive D-97-08 (1st revision). Canadian Food Inspection Agency, Ottawa, Ontario, Canada, 23 Nov. 2004.

Converse R.H. (ed.). 1987. Virus diseases of small fruits. U.S. Dept. Agr., Agr. Handbook No. 631. U.S. Govt. Printing Office, Washington, D.C.

Damiano, C. 1980. Strawberry micropropagation, p. 11-21. In: Proc. Conf. Nursery Production of Fruit Plants through Tissue Culture: Applications and Feasibility, Beltsville, MD, 21-23 Apr. 1980.

Freeman, S. 2008. Management, survival strategies and host range of Colletotrichum acutatum on strawberry. HortScience 43:66-68.

Gaines, C. 2005. An integrated approach to managing Colletotrichum acutatum through the use of meristem plants, nursery isolation and sanitation measures. In: Anthracnose on strawberry: management strategies for plant and runner tip nurseries. Video Workshop Series, Disk 2. Amer. Soc. Hort. Sci., Alexandria, VA.
George, E.F. 1993. Plant propagation by tissue culture. 2nd ed. Exegetics Ltd., Edington, England.

George, E.F. and P.D. Sherrington. 1984. Plant propagation by tissue culture. Handbook and directory of commercial laboratories. Exegetics Ltd., Eversley, England.

Hughes, B.R. 2002. Micropropagated strawberries in the Ontario plant propagation program, p. 93-97. In: S.C. Hokanson and A.R. Jamieson (eds.). Proc. 5th N. Amer. Strawberry Conf.: Strawberry Res. to 2001. ASHS Press, Alexandria, VA.

Jelenkovic, G., C. Chin, S. Billings, and J. Eberhardt. 1991. Transformation studies in cultivated strawberry, Fragaria Xananassa Duch., p. 91-97. In: A. Dale and J.J. Luby (eds.). The strawberry into the 21 st century. Timber Press, Portland, OR.

Jungnickel, F. 1988. Strawberries (Fragaria spp. and hybrids), p. 38-103. In: Y.P.S. Baja (ed.). Biotechnology in agriculture and forestry, Vol. 6, Crops II. Springer-Verlag, Berlin, Germany.

Khayat, E., A. Adbul Razek, D. Halevy, and T. Guntmacher. 1997. Effective cleaning of strawberry plants from pathogenic fungal and endophytic bacterial contaminants. Acta Hort 439:369-372.

Kunneman, B.P.A.M. and G.P.M. Faaij-Groenen 1988. Elimination of bacterial contaminants: a matter of detection and transplanting procedures. Acta Hort. 225:183-188.

Leifert, C., W.M. Waites, and J.R. Nicholas. 1989 Bacterial contaminants of micropropagated plant cultures. J. Appl. Bacteriol. 67:353-361.

López-Aranda, J.M., F. Pliego-Alfaro, I. LópezNavidad, and M. Barceló-Muñoz. 1994. Micropropagation of strawberry (Fragaria xananassa Duch.). Effect of mineral salts, benzyladenine levels and number of subcultures on the in vitro and field behaviour of the obtained microplants and the fruiting capacity of their progeny. J. Hort. Sci. 69:625-637.

Martin, R.R. 2001. Appendix I. Recommended procedures for detection of viruses in small fruit crops. Acta Hort. 551:113-121.

Martinelli, A. 1992. Micropropagation of strawberry (Fragariaspp.), p. 354-370. In: Y.P.S Baja (ed.). Biotechnology in agriculture and forestry, Vol. 18. High-tech and micropropagation, II. Springer-Verlag, Berlin, Germany.

Neal, J.C., M.P. Pritts, and A.F. Senesac. 1990 Evaluation of preemergent herbicide phytotoxicity to tissue culture-propagated 'Heritage' red raspberry. J. Amer. Soc. Hort. Sci. 15: 416-422.

Shoemaker, N.P., H.J. Swartz, and G.J. Galletta. 1985. Cultivar dependent variation in pathogen resistance due to tissue culture-propagation of strawberries. HortScience 20:253-254.

Smith, B.J. 2008. Epidemiology and pathology of strawberry anthracnose: a North American perspective. HortScience 43:69-73.

Sward, R.J. and N.D. Hallam. 1977. Changes in the fine structure of the potato meristem following heat treatment for virus eradication. Aust. J. Bot. 24:597-605.

Swartz, H.J., G.J. Galletta, and R.H. Zimmerman 1981. Field performance and phenotypic stability of tissue culture-propagated strawberries. J. Amer. Soc. Hort. Sci. 105:667-673.

Swartz, H.J. and J.T. Lindstrom. 1986. Small fruit and grape tissue-culture from 1980 to 1985 : commercialization of the technique, p. 201220. In: H. Zimmerman, R.S. Reisbach, F.A Hammerslag, and R.H. Lawson (eds.). Tissue culture as a plant production system for horticultural crops. Martinus Nijhoff Publishers, Dordrecht, Holland. 